\title{
Foliar application of plant-based biostimulants improve yield and upgrade qualitative characteristics of processing tomato
}

\author{
Eugenio Cozzolino, ${ }^{1}$ Ida Di Mola, ${ }^{2}$ Lucia Ottaiano, ${ }^{2}$ Christophe El-Nakhel, ${ }^{2}$ Youssef Rouphael, ${ }^{2}$ \\ Mauro Mori ${ }^{2}$ \\ ${ }^{1}$ Council for Agricultural Research and Economics (CREA), Research Centre for Cereal and Industrial \\ Crops, Caserta; ${ }^{2}$ Department of Agricultural Sciences, University of Naples Federico II, Portici (NA), Italy
}

\author{
Highlights \\ - The effects of three plant-based biostimulants on yield and quality of processing tomato was explored. \\ - Application of protein hydrolysates and seaweed extract improve marketable yield. \\ - The biostimulants had different effect on nutritional and functional quality of tomato. \\ - Hydrophilic antioxidant activity and ascorbic acid content increased under protein hydrolysate application.
}

\begin{abstract}
Tomato (Solanum lycopersicum L.) is a diffused worldwide vegetable. Great amounts of fertilizers are often applied for increasing yield and quality, without considering the negative effect on the environment. A possible perspective for reducing this risk is to raise the nitrogen use efficiency (NUE) through the use of plant biostimulants, which also improve yield and quality concomitantly. The aim of the current study was to verify the potential beneficial effect of three vegetal-based biostimulants on agronomical, qualitative and nitrogen use efficiency of a processing tomato crop. The experiment provided three biostimulants (an extract of brown seaweed [SwE], a legume-derived protein hydrolysate [LDPH] and a tropical plant extract). The following assessments were carried out: marketable and unmarketable yields, mean fruits weight, firmness, $\mathrm{pH}$, total soluble solids (TSS), colour parameters $(\mathrm{a} / \mathrm{b})$, hydrophilic antioxidant activity (HAA), lipophilic antioxidant activity (LAA), total ascorbic acid content (AsA), total phenols, nitrate and total nitrogen content, nitrogen use effi-
\end{abstract}

Correspondence: Ida Di Mola, Department of Agricultural Sciences, University of Naples Federico II, Portici (NA), Italy.

E-mail: ida.dimola@unina.it

Key words: Solanum lycopersicum L.; sustainable agriculture; tropical plant extract; seaweed; protein hydrolysates; fruits quality; soluble solids; nitrogen efficiency.

Received for publication: 31 January 2021.

Revision received: 15 March 2021.

Accepted for publication: 20 March 2021.

${ }^{\circ}$ Copyright: the Author(s), 2021

Licensee PAGEPress, Italy

Italian Journal of Agronomy 2021; 16:1825

doi:10.4081/ija.2021.1825

This article is distributed under the terms of the Creative Commons Attribution Noncommercial License (by-nc 4.0) which permits any noncommercial use, distribution, and reproduction in any medium, provided the original author(s) and source are credited. ciency, $\mathrm{N}$-uptake efficiency, and N-utilization. The foliar application of biostimulants especially protein hydrolysates and seaweed extract significantly affected the marketable yield with an average increase of $18.3 \%$ over the control and $41.3 \%$ average decrease in unmarketable yield. The $\mathrm{N}$-use and $\mathrm{N}$-uptake efficiency followed a similar trend, with biostimulants boosting it higher than control, $+18.4 \%$ and $+59.3 \%$, respectively; the nitrogen content was also higher in fruits of sprayed plants: $+21.3 \%$ over control. This finding also reflects on higher dry matter accumulation and firmness in fruits of treated plants $(+10.9 \%$ and $+14.1 \%$ over control, respectively). The biostimulants application, in particular SwE and LDPH, also boosted TSS $(+12.8 \%)$, the a/b colour ratio (+7.5\%), HAA and AsA (9.8\% and $114.6 \%$, respectively). Therefore, the legume-derived protein hydrolysates and extract of brown seaweed Ecklonia maxima seem a good sustainable approach to improve yield and quality of tomato for canning industries.

\section{Introduction}

Tomato (Solanum lycopersicum L.) is among the most diffused vegetables in the world. Improving commercial yield, size, shape, firmness, colour, taste, and solid content of fruit represent the main goals to increase commercial values of this vegetable (Del Giudice et al., 2016). These quality attributes as well as the yield are affected by climatic conditions and the agronomic management (irrigation, fertilisation, weed control, etc.) (Kalt, 2005; Flores et al., 2009). For improving tomato production, the intensive application of chemical fertilizers has thrived as an ordinary practice among the farmers, notwithstanding its collateral damage to soil ecology and agricultural systems (Villarreal-Sánchez et al., 2003). A viable perspective for reducing the risks linked to excessive or unbalanced use of chemical fertilizer is to raise the nitrogen use efficiency (NUE) that depends on the capacity of plants to uptake nutrients, as well as on their systems of transport, storage, and the mobilization, other than the $\mathrm{N}$ loss into the environment (Hawkesford et al., 2014). In the last two decades, the use of plant biostimulants have been coupled to biotechnology and plant breeding strategies to improve NUE (Calvo et al., 2014; Di Mola 
et al., 2020a). Plant biostimulants are considered an important and sustainable approach to enhance the nutritional and functional quality of vegetable products and to maintain soil fertility (du Jardin, 2015). As emphasized by du Jardin (2015), biostimulants are used to improve nutrient uptake and increase yield and crop quality, stimulating natural processes in different conditions. Most researchers reported that the application of plant biostimulants can increase plant growth and development, productivity, and nutritional quality (Parađiković et al., 2011; Koukounararas et al., 2013; Ertani et al., 2014; Bulgari et al., 2015); moreover, it enhances soil-conditions influencing its microflora, modifying the root system architecture, and boosting their development (Caruso et al., 2019a; Di Mola et al., 2019). Nowadays, among the marketed biostimulants, seaweed extracts, particularly the brown algae (Phaeophyceae), protein hydrolysates, and plant extracts are the most representative plant-based biostimulant categories.

Biostimulants can be applied through foliar application or soil/substrate drenching. When the biostimulant is sprayed on the leaves, it is absorbed through the cuticle, epidermal cells and stomata (Fernández and Eichert, 2009); instead with drenching technique, it is absorbed through root epidermal cells and gets redistributed through the xylem (Subbarao et al., 2015). Biostimulants can modify the primary and secondary metabolism of plants, improving productivity and decreasing the impact of abiotic stress on crops (Calvo et al., 2014; Rouphael et al., 2017a). Some biostimulants, as extracts rich in amino acids, improve tolerance to heat stresses (Colla et al., 2014; Nardi et al., 2016; Lucini et al., 2015) and to saline stress (Di Mola et al., 2021). Van Oosten et al. (2017) reported that lettuce plants treated with a hydrolysed protein based biostimulant, under cold stress showed higher fresh weight and better stomatal conductance compared to non-treated plants. More researches reported that the application of vegetalbased biostimulants on lettuce and tomato determined a significant increase of the nutritional and functional quality of edible tissues (Caruso et al., 2019b; Cozzolino et al., 2020). Also, Di Mola et al. (2020b) reported that the foliar application of biostimulants, especially seaweed extract and protein hydrolysates, improved the quality of baby leaf lettuce grown under different nitrogen levels, including non-fertilized ones. The effect of plant-derived biostimulants and seaweed extracts on yield and fruit quality of tomato are reported in a few articles. Colla et al. (2017a) reported a better yield and quality in greenhouse tomato treated with these biostimulants; these improvements were more evident with the foliar application of the commercial tropical plant extract 'Auxym'. Furthermore, Rouphael et al. (2017b) observed that tomatoes treated with legume-derived protein hydrolysate 'Trainer' accumulated more total solids soluble, lycopene, $\mathrm{K}$, and $\mathrm{Mg}$ contents compared to untreated plants. Although the use of biostimulants increases production costs, Colla et al. (2017a) demonstrated that the yield increase of treated plants brings to higher gross returns and consequently also higher net returns, as compared to untreated plants cultivation. Based on the above mentioned and starting from the findings of Colla et al. (2017a), the aim of the present study was to verify the potential beneficial effect of the same three vegetalbased biostimulants on a processing tomato, a different variety in respect to Colla et al. (2017a), evaluating not only yield, and physical, chemical, and nutritional traits of fruits but also the biostimulants effect on nitrogen use, utilization, and uptake efficiency.

\section{Materials and methods}

\section{Experimental site and design, crop management and biostimulant applications}

The experiment was carried out in open field during the springsummer growing season 2019, at the Department of Agricultural Sciences (Portici, NA, Southern Italy). The soil was sandy loam ( $70 \%$ sand, $12 \%$ silt, $18 \%$ clay), with a $\mathrm{pH}$ of 8.0 , electrical conductivity (EC) of $0.25 \mathrm{dS} \mathrm{m}^{-1}, 2.0 \%$ organic matter, $0.13 \%$ total

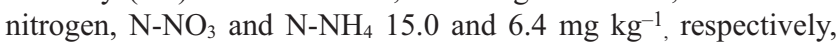
$\mathrm{P}_{2} \mathrm{O}_{5} 75 \mathrm{mg} \mathrm{kg}^{-1}$, and exchangeable $\mathrm{K}_{2} \mathrm{O} 758 \mathrm{mg} \mathrm{kg}^{-1}$.

The tested crop was tomato (Solanum lycopersicum L.) 'Coronel' (ISI Sementi, Parma, Italy) F1 hybrid showing very consistent oval fruit, was adopted. The experimental plan consisted of a randomized complete-block design with three replicates per each treatment. The three treatments/biostimulants based on: an extract of brown seaweed Ecklonia maxima (Osbeck) - SwE; a legumederived protein hydrolysate - LDPH; and a tropical plant extract TPE, were compared with an untreated control.

The SwE is made by Kelpak Products (Ltd., Cape Town, South Africa), and marketed with the trade name $\operatorname{Kelpak}{ }^{\circledR}$; the $L D P H$, known with the trade name Trainer ${ }^{\circledR}$, and the TPE, marketed with the trade name Auxym $\AA$, are produced by Italpollina S.p.A. (Rivoli Veronese, Italy). The elemental composition of the three biostimulants were reported by in Colla et al. (2017a).

Each experimental plot was $17.2 \mathrm{~m}^{-2}(5.60 \times 3.08 \mathrm{~m})$ and 55 plants per plots were transplanted on June 10 in single rows, corresponding to a plant density of 32.467 per ha. Before the transplant, a biodegradable black mulching film (15 $\mu \mathrm{m}$ thick MaterBi $^{\circledR}$, Novamont, Novara, Italy) was hand-placed on each row. Based on the Campania Region Fertilization Guide, the nutrient needs were calculated: potassium $(\mathrm{K})$ was not needed, while phosphorus $(\mathrm{P})$ was applied as mineral superphosphate at the rate of $20 \mathrm{~kg} \mathrm{ha}^{-1}$ before the transplant and nitrogen (N) was applied as ammonium nitrate and calcium nitrate at the rate of $130 \mathrm{~kg} \mathrm{ha}^{-1}$ of nitrogen by fertigation. Irrigations were made on a weekly basis, and they were stopped 10 days before harvest; the water lost by evapotranspiration was calculated by the Hargreaves formula and was completely restored. As for the biostimulants, the application started on June 25 on a bi-weekly basis, for a total of four applications; SwE and TPE were sprayed at a concentration of $2 \mathrm{~mL} \mathrm{~L}^{-1}$, and $\mathrm{LDPH}$ at $3 \mathrm{~mL} \mathrm{~L}^{-1}$, according to the manufacturers' recommendations, while control plants were sprayed with tap water. The harvest of tomato plants was on September 6.

\section{Yield assessments}

At harvest, on 20 plants taken from the two central rows of each experimental plot, the fresh weight of marketable and unmarketable yield were weighted, and mean fruit weight were calculated, by dividing the fruit fresh weight by the number of fruits. The yield was expressed as tons $\mathrm{ha}^{-1}$. Then, a sample of plant biomass (stems and leaves) and fruits per each replicate (experimental plot) was oven-dried at $70^{\circ} \mathrm{C}$, until reaching a constant weight in order to determine dry matter.

\section{Physical, chemical and nutritional traits of tomato fruits}

The following physical, chemical and nutritional traits of tomato fruits were investigated: firmness, juice $\mathrm{pH}$, total soluble solids (TSS), colour parameters $(\mathrm{a} / \mathrm{b})$, hydrophilic/lypophilic antioxidant activities (HAA and LAA, respectively), total ascorbic acid content (AsA), and total phenols. Firmness was performed on the two sides of the equa- 
torial zone of five fruits per replicate, using a digital penetrometer (T.R. Turoni s.r.l., Forlì, Italy) with an $8 \mathrm{~mm}$ tip. The applied force for $4 \mathrm{~mm}$ penetration was expressed in $\mathrm{kg} \mathrm{m}^{-2}$. On fresh fruit juice, $\mathrm{pH}$ and TSS were assessed, using a digital pH-meter (METTLER TOLEDO MP 220) and a portable digital refractometer (Sinergica Soluzioni s.r.l., Pescara, Italy, model DBR 35), respectively. The TSS were expressed as ${ }^{\circ}$ Brix. On ten-fruit samples per each treatment the colour space parameters ( $\mathrm{a}^{*}$ and $\mathrm{b}^{*}$ ) were measured by a portable Hunter Lab Colorimeter (3NH model 310). The data were reported as red/yellow ratio $(\mathrm{a} / \mathrm{b})$. The hydrophilic and lipophilic antioxidant activity and total phenols were determined on fresh vegetable samples, after freezing and lyophilizing, where AsA was determined on freeze fresh material. HAA, LAA and AsA were assessed spectrophotometrically, according to methods of Fogliano et al. (1999), Re et al. (1999), and Kampfenkel et al. (1995), respectively. The absorbance of solutions was measured at 505, 734, and $525 \mathrm{~nm}$, for HAA, LAA and AsA, respectively. Finally, total phenols content was determined by Folin-Ciocalteau procedure (Singleton et al., 1999).

\section{Nitrogen determination, and N-use, -uptake, and -uti- lization efficiency}

The nitrate content and total nitrogen content of fruits were determined on dried samples by Foss FIAstar 5000 continuous flow Analyzer (FOSS analytical Denmark), based on colorimetric and Kjeldhal method (Bremner, 1965), respectively. Nitrogen use efficiency was calculated by dividing fresh yield by $\mathrm{N}$ applied (Aujla et al., 2007); moreover, N-uptake efficiency was determined as the ratio between the nitrogen content of fruits and $\mathrm{N}$ applied; N-utilization was instead calculated as the ratio between fresh yield and nitrogen content of fruit. All three efficiency parameters were expressed as $\mathrm{kg} \mathrm{kg}^{-1}$.

\section{Statistical analysis}

All data were subjected to the analysis of variance (one wayANOVA), using a general linear model by the SPSS software package. Means were separated according to the Duncan's multiple range test at $\mathrm{P} \leq 0.05$.

\section{Results and discussion}

\section{Effects of biostimulants on yield and its parameters}

The results regarding marketable and unmarketable yield of tomato are reported in Figure 1. The foliar application of biostimulants, significantly increased marketable yield respect to the untreated control $(+18.3 \%$, on average). This mean increase was about double than the improvement for greenhouse tomato reported by Colla et al. (2017a), who also reported Auxym (TPE) as the best treatment in improving marketable yield. On the contrary, we found that LDPH and SwE reached higher similar values (76.8 and $78.8 \mathrm{t} \mathrm{ha}^{-1}$, respectively) than TPE treatment $\left(72.6 \mathrm{tha}^{-1}\right)$. The positive effect of SwE on marketable yield was also observed by Ali et al. (2016), who applied Ascophyllum nodosum seaweed extract on the foliage of tomato plants. The ascribed beneficial effect of this biostimulant is due to the present polysaccharides, which improved plant productivity by enhancing endogenous hormone homeostasis (Rolland et al., 2002). Regarding the effect of LDPH 'Trainer', Colla et al. (2014) highlighted that the used biostimulant triggers an auxin-like and to a lesser extent a gibberellin-like activities; moreover, de Jong et al. (2009) reported that the gibberellins also play an important role in the onset of tomato fruit development by controlling both the expression of the genes regulating cell division and cell expansion in fruits. Additionally, Caruso et al. (2019b) observed similar results in cherry-like tomato landrace 'Piennolo del Vesuvio' treated with LDPH and TPE, which increased marketable yield around $+14.9 \%$ over control. In addition, in our research all three biostimulants significantly affected the unmarketable yield, by reducing its incidence about $41.3 \%$ (on average) compared to control. The findings of our research highlight a similar overall response of tomato to the three plant-based biostimulants, but within the specie each variety seems to respond differently to the single biostimulant.

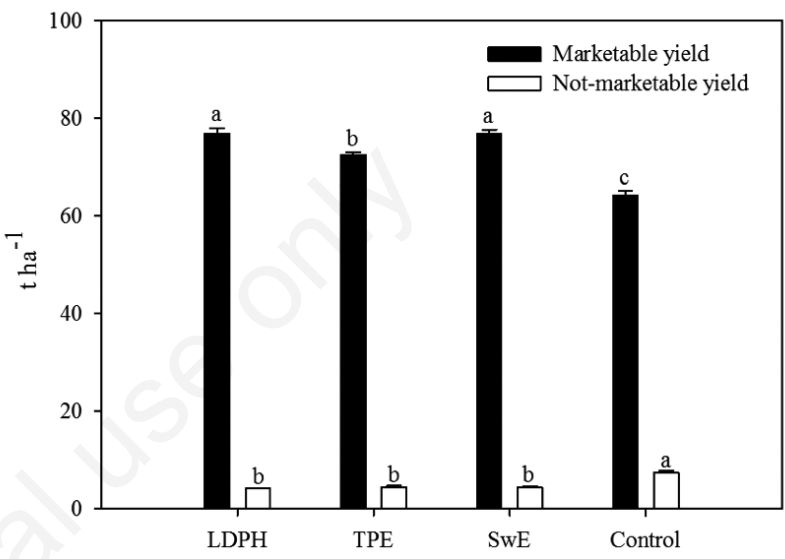

Figure 1. Marketable and unmarketable fruits of tomato as affected by biostimulants application. LDPH, legume-derived protein hydrolysates; TPE, tropical plant extract; SwE, seaweed Ecklonia maxima; Control, untreated. Different letters indicate significant differences according to Duncan's multiple range test $(\mathbf{P} \leq 0.05)$.

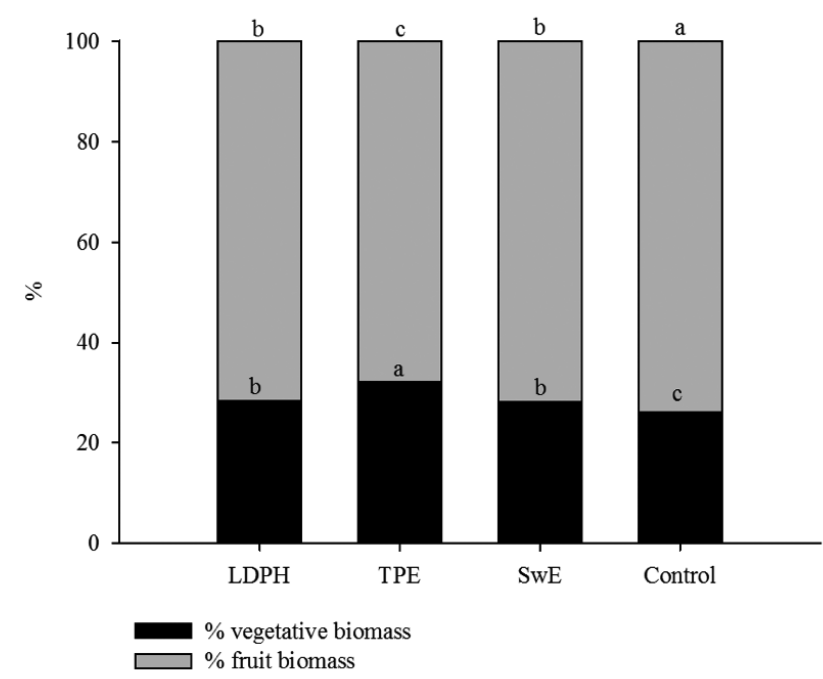

Figure 2. Percentage repartition of dry matter between vegetative and fruit biomass of tomato as affected by biostimulants application. LDPH, legume-derived protein hydrolysates; TPE, tropical plant extract; SwE, seaweed Ecklonia maxima; Control, untreated. Different letters indicate significant differences according to Duncan's multiple range test $(P \leq 0.05)$. 
The biostimulants treatment had a significant effect as well on the percentage repartition of dry matter between plant biomass and tomato fruits (Figure 2). All three biostimulants stimulated the plant biomass development, as highlighted by a higher incidence of vegetable biomass on total dry matter in sprayed plants respect to untreated plants $(+13.1 \%)$. In particular, this increment was significantly higher for TPE treated plants compared to the other two biostimulants. A possible explanation of the TPE effect, could be both the stimulation of root growth of treated plants and the presence of phytohormones (e.g., auxins) and signalling compounds (e.g., amino acids, vitamins, phytochelatins), with an overall development of plants (Colla et al., 2017a).

\section{Nitrogen use, uptake, and utilization efficiency}

The used biostimulants significantly affected nitrogen use, uptake and utilization efficiency, as well as total nitrogen content of tomato fruits. The N-use and N-uptake efficiency followed a similar trend, highlighting increased values than the control $(+18.4 \%$ and $+59.3 \%$, respectively). Anyway, the seaweed extract and legume derived-PH promoted the best effect (Table 1). Instead, the N-Utilization efficiency showed an opposite trend, with untreated control showing higher values than the three biostimulants $(+32.9 \%)$. Finally, it was notable that total nitrogen content was higher in fruits of treated plants $(+21.3 \%$ over the control). In a previous research (Di Mola et al., 2020a), LDPH application proved to enhance the N-Use and N-Uptake efficiency in baby spinach and lamb's lettuce.

The nitrogen efficiency parameters represent very important indicators of the $\mathrm{N}$ metabolism in plants; in fact, a high supply of nitrogen does not always correspond to high yield, because this element can accumulate in other organs (stems and roots) or leached in the soil like nitrate. Furthermore, Du et al. (2017) and Ronga et al. (2019) observed low values of NUE in tomato plants fertilized with higher doses of nitrogen than the N0-control; Djidonou et al. (2013) also obtained the same results, regardless of the different experimental conditions. In addition, Cammarano et al. (2020) investigated the role of projected changes and increased $\mathrm{CO}_{2}$ on the water and nutrient efficiency of tomato and they found that the impact of the $\mathrm{CO}_{2}$ on the crop physiological efficiencies was positive for the NUE and WUE, but these efficiencies decreased when the irrigation and fertilization was optimized. Our findings reflected the yield increase occurring in plants treated with LDPH and SwE, but the increase in N-uptake efficiency also resulted in an accumulation of nitrogen in tomato fruits. On the other hand, LDPH in other researches already showed its ability to boost crops' resources use efficiency (in terms of water and nutrients) (Colla et al., 2017b; Rouphael et al., 2018b), especially $\mathrm{N}$ uptake and assimilation. The positive effect of foliar application of LDPH on the $\mathrm{N}$ efficiency parameters can be due to the improvement of root architecture, which is related to an increase in nutrient accessibility caused by its ability to boost the capacity of absorption, translocation and assimilation of macro and micro-minerals (Ertani et al., 2009; Schiavon et al., 2008). Finally, the highest value of N-Utilization (ratio between fresh yield and $\mathrm{N}$ removed by fruits) recorded for the control, suggested that untreated plants although producing less but did remove a quantity of nitrogen lower as well, that was totally used for sustaining yield (high $\mathrm{N}$ Utilization efficiency), at the expense of $\mathrm{N}$ content in fruits.

\section{Physical, chemical and nutritional traits of tomato fruits}

Total soluble solids content, $\mathrm{pH}, \mathrm{a} / \mathrm{b}$ colour, firmness, fruit weight and dry matter content were reported in Table 2; all parameters except $\mathrm{pH}$ were significantly affected by biostimulant treatments.

In our research, applied biostimulant increased FW compared to the untreated control (82.3 vs $69.8 \mathrm{~g}$ fruit $^{-1}$, respectively) with LDPH showing significantly higher effect than TPE (Table 2). These results resembled the effect induced on yield, highlighting a good correlation (0.988) between the two parameters The adopted

Table 1. Effect of biostimulants application on nitrogen $(\mathrm{N})$ use efficiency, nitrogen uptake efficiency, nitrogen utilization efficiency, and $\mathbf{N}$ total content of tomato fruits.

\begin{tabular}{|c|c|c|c|c|}
\hline Treatments & $\begin{array}{l}\text { N-Use efficiency } \\
\qquad \mathrm{kg} \mathrm{kg}^{-1}\end{array}$ & $\begin{array}{l}\text { N-Uptake efficiency } \\
\qquad \mathrm{kg} \mathrm{kg}^{-1}\end{array}$ & $\begin{array}{l}\text { N-Utilization efficiency } \\
\qquad \mathrm{kg} \mathrm{kg}^{-1}\end{array}$ & $\begin{array}{c}\text { Total N } \\
\%\end{array}$ \\
\hline \multicolumn{5}{|l|}{ Biostimulants } \\
\hline SwE & $606.4^{\mathrm{a}}$ & $0.92^{\mathrm{ab}}$ & $668.1^{\mathrm{b}}$ & $2.47^{\mathrm{ab}}$ \\
\hline TPE & $558.4^{\mathrm{b}}$ & $0.84^{\mathrm{b}}$ & $678.8^{\mathrm{b}}$ & $2.58^{\mathrm{a}}$ \\
\hline LDPH & $591.0^{\mathrm{a}}$ & $1.06^{\mathrm{a}}$ & $560.8^{\mathrm{b}}$ & $2.82^{\mathrm{a}}$ \\
\hline Control & $494.5^{c}$ & $0.59 c$ & $845.3^{\mathrm{a}}$ & $2.16^{\mathrm{b}}$ \\
\hline Significance & $* *$ & $* *$ & $*$ & $*$ \\
\hline
\end{tabular}

SwE, seaweed Ecklonia maxima; TPE, tropical plant extract; LDPH, legume-derived protein hydrolysates; Control, untreated. *, ${ }^{* *}$ Significant at $\mathrm{P}<0.05$ or $\mathrm{P}<0.01$, respectively. a-cDifferent letters within each column indicate significant differences according to Duncan's multiple range test $\mathrm{P} \leq 0.05$.

Table 2. Effect of biostimulants application on total soluble solids, $\mathrm{pH}$, colour $\mathrm{a} / \mathrm{b}$, firmness, fruit average weight, fruit dry matter.

\begin{tabular}{|c|c|c|c|c|c|c|}
\hline Treatments & $\begin{array}{l}\text { TSS } \\
{ }^{\circ} \text { Brix }\end{array}$ & pH & Colour $\mathbf{a} / \mathbf{b}$ & $\begin{array}{l}\text { Firmness } \\
\mathrm{kg} \mathrm{cm}^{-2}\end{array}$ & $\begin{array}{l}\text { FAW } \\
\text { g fruit }^{-1}\end{array}$ & $\begin{array}{c}\text { DM fruit } \\
\%\end{array}$ \\
\hline \multicolumn{7}{|l|}{ Biostimulants } \\
\hline SwE & $5.87^{\mathrm{a}}$ & 4.22 & $2.59^{\mathrm{a}}$ & $0.82^{\mathrm{a}}$ & $86.1^{\mathrm{a}}$ & $6.10^{a b}$ \\
\hline TPE & $5.47^{\mathrm{b}}$ & 4.23 & $2.48^{b}$ & $0.76^{\mathrm{b}}$ & $78.4^{\mathrm{b}}$ & $5.83^{\mathrm{b}}$ \\
\hline LDPH & $5.97^{\mathrm{a}}$ & 4.18 & $2.64^{\mathrm{a}}$ & $0.84^{\mathrm{a}}$ & $82.5^{\mathrm{a}}$ & $6.37^{\mathrm{a}}$ \\
\hline Control & $5.13^{b}$ & 4.22 & $2.39 \mathrm{c}$ & $0.71^{\mathrm{c}}$ & $69.8^{\mathrm{c}}$ & $5.50^{\mathrm{c}}$ \\
\hline Significance & $* *$ & NS & $* *$ & $* *$ & $* *$ & $*$ \\
\hline
\end{tabular}

TSS, total soluble solids; FAW, fruit average weight; DM, dry matter; SwE, seaweed Ecklonia maxima; TPE, tropical plant extract; LDPH, legume-derived hydrolysate proteins; Control, not treated; NS, non-significant. *, ** Significant at $\mathrm{P}<0.05$ or $\mathrm{P}<0.01$, respectively. a-cDifferent letters within each column indicate significant differences according to Duncan's multiple range test $\mathrm{P} \leq 0.05$. 
Table 3. Effect of biostimulants application on lipophilic antioxidant activity, hydrophilic antioxidant activity, phenols and ascorbic acid.

\begin{tabular}{|c|c|c|c|c|}
\hline Treatments & $\begin{array}{c}\text { LAA } \\
\text { mmol Trolox } 100 \mathrm{~g}^{-1} \mathrm{dw}\end{array}$ & $\begin{array}{c}\text { HAA } \\
\text { mmol AA } 100 \mathrm{~g}^{-1} \mathrm{dw}\end{array}$ & $\begin{array}{l}\text { Phenols } \\
\text { mg gallic acid } \mathrm{g}^{-1} \mathrm{dw}\end{array}$ & $\begin{array}{c}\text { AsA } \\
\mathrm{mg} 100 \mathrm{~g}^{-1} \mathrm{fw}\end{array}$ \\
\hline \multicolumn{5}{|l|}{ Biostimulants } \\
\hline SwE & $8.86^{\mathrm{ab}}$ & $11.19^{a}$ & 1.39 & $61.86^{\mathrm{b}}$ \\
\hline TPE & $9.02^{\mathrm{a}}$ & $8.66^{\mathrm{c}}$ & 1.38 & $40.15^{c}$ \\
\hline LDPH & $8.47^{\mathrm{c}}$ & $10.76^{\mathrm{a}}$ & 1.49 & $83.37^{\mathrm{a}}$ \\
\hline Control & $8.57^{\mathrm{bc}}$ & $10.00^{b}$ & 1.41 & $33.84^{\mathrm{c}}$ \\
\hline Significance & $* *$ & $* *$ & NS & $* *$ \\
\hline
\end{tabular}

LAA, lipophilic antioxidant activity; HAA, hydrophilic antioxidant activity; AsA, ascorbic acid; SwE, seaweed Ecklonia maxima; TPE, tropical plant extract; LDPH, legume-derived hydrolysate proteins; Control, not treated. **Significant at $\mathrm{P}<0.01$, respectively. ${ }^{\text {a-c }}$ Different letters within each column indicate significant differences according to Duncan's multiple range test $\mathrm{P} \leq 0.05$.

biostimulants did not seem to influence the number of fruits per plant, that was 28.5 (mean value of three biostimulants) vs 28.4 of the control (data not reported).

The biostimulants application also promoted dry matter accumulation in the fruits, whose increasing was about $10.9 \%$ than control (Table 2). This finding could be partially related to the improved $\mathrm{N}$ fruit content in the treated plots. Likewise, firmness showed a similar trend, with $14.1 \%$ increase respect to untreated plants (Table 2). Several authors reported that fruit firmness is related to membrane properties, cell size and wall structure (Chapman et al., 2012; Huang et al., 2018) and represent an important indicator of tomato fruit quality. Maach et al. (2020) found that the application of two biostimulants (Tecamin Flower and Tecamin Brix), alone or combined, improved firmness of tomato fruits, probably because the algal extract has a beneficial effect on turgidity and wall components (Hawkesford et al., 2012). Our findings were in line with these results, highlighting a greater effect of Seaweed algal extract and LDPH on firmness, than TPE and untreated control.

Total soluble solids (measured as ${ }^{\circ}$ Brix), are the soluble part (sugars, acids, mineral salts) of dry matter of tomato fruit, and represent one of the most important quality traits for tomato industries and for consumer (Kader, 2002). The biostimulants application increased TSS in biostimulant-treated plants compared to the control $(+12.8 \%$ as reported in Table 2). Colla et al. (2017a) and Ertani et al. (2014) also found an increase in TSS, glucose and sucrose in tomato and chili pepper when plants were treated with LDPH and biostimulants based on alfalfa and red grape, respectively.

The colour is one of the most important physical parameters, both for fresh and processed tomato; in this crop it is mainly linked to lycopene biosynthesis, which is under genetic control and depends on the temperature (Brandt et al., 2006). The colour is also affected by irrigation (Nangare et al., 2016) and nitrogen fertilization (Ronga et al., 2020). Values greater than 1.70 up to 2.60 are desirable for canned products. In our research, the $a / b$ values ranged from 2.39 for the control up to 2.64 for LDPH-treated tomatoes; the all three biostimulant improved colour parameters $(+7.5 \%$ over control), with TPE-treatment being less effective than SwE and LDPH (Table 2).

Low juice $\mathrm{pH}$ of processed tomato is crucial in controlling the proliferation of harmful microorganisms in processed products; values inferior to 4.3 require temperatures lower than $100^{\circ} \mathrm{C}$ for sterilization. In our study, biostimulant application did not affect the $\mathrm{pH}$ of fruit juice ( $\mathrm{pH}=4.21$ as means of all treatments), which was optimal for tomato canning. Our results were consistent with those of Colla et al. (2017a) and Rouphael et al. (2017b) reporting no effects of biostimulants on tomato $\mathrm{pH}$.

The lipophilic and hydrophilic antioxidant capacities represent good parameters to evaluate the tomato nutritional quality. These two measurements concern antioxidant molecules having a beneficial effect on human health, delaying or/inhibiting oxidative damage, hence evading a broad range of diseases (Khanam et al., 2012; Kyriacou and Rouphael, 2018). In our research, the lipophilic and hydrophilic antioxidant activities, as well as the total ascorbic acid were affected by biostimulants application. Indeed, SwE and LDPH application increased HAA and AsA (+9.8\%, and $+114.6 \%$ in, respectively), LAA was instead improved by application of SwE and TPE which were statistically comparable (Table 3). Our findings are consistent with the results reported by Caruso et al. (2019b) showing a beneficial effect of LDPH on AsA and TPE on LAA of a cherry-like tomato landrace. The synthesis and built up of bioactive compounds like AsA (LAA) can be correlated to indirect or direct aftermath of the application of biostimulants on the formation of antioxidants in plant tissues (Rouphael et al., 2017b). For instance, as mentioned by the same authors, plant-derived protein hydrolysates can promote the activity of certain enzymes tangled in antioxidant cells homeostasis, or an indirect effect such potassium accumulation can lead to the increase of fruit antioxidants.

\section{Conclusions}

The findings of the current research indicate that foliar application of plant-based biostimulants improved tomato yield and mean fruit weight, especially when legume-derived protein hydrolysates and seaweed extract were applied. The effect of these biostimulants on yield is probably due to their beneficial effect on nitrogen use efficiency ( $\mathrm{N}$ uptake and the $\mathrm{N}$-use). Moreover, some quality attributes of tomato fruits (TSS, colour and firmness) were improved by the same two biostimulants, offering additional benefits to tomato industry both on the qualitative and the economic aspects.

Therefore, the use of the legume-derived protein hydrolysates and extract of brown seaweed Ecklonia maxima seem a good sustainable approach to improve yield and quality of processing tomato. However, future research seems necessary in order to verify the effect of these commercial products in different environmental and on varieties showing different fruit type and length of the crop cycle. 


\section{References}

Ali N, Farrell A, Ramsubhag A, and Jayaraman J, 2016. The effect of Ascophyllum nodosum extract on the growth, yield and fruit quality of tomato under tropical conditions. J. Appl. Phycol. 28:1353-62.

Aujla MS, Thind HS, Buttar GS, 2007. Fruit yield and water use efficiency of eggplant (Solanum melongema L.) as influenced by different quantities of nitrogen and water applied through drip and furrow irrigation. Sci. Hortic. 112:142-8.

Brandt S, Pék Z, Barna É, Lugasi A, Helyes L, 2006. Lycopene content and colour of ripening tomatoes as affected by environmental conditions. J. Sci. Food Agri. 86:568-72.

Bremner JM, 1965. Total nitrogen. pp 1149-1178 in C.A. Black, D.D. Evans, I.L. White, L.E. Ensminger, F.E. Clark (Eds.), Methods of soil analysis, Part 2: Chemical and microbiological properties. American Society of Agronomy, Madison, WI, USA.

Bulgari R, Cocetta G, Trivellini A, Vernieri P, \& Ferrante A, 2015. Biostimulants and crop responses: a review. Bio. Agri. Hort. 31:1-17.

Calvo P, Nelson L, Kloepper JW, 2014. Agricultural uses of plant biostimulants. Plant Soil. 383:3-41.

Cammarano D, Ronga D, Di Mola I, Mori M, Parisi M, 2020. Impact of climate change on water and nitrogen use efficiencies of processing tomato cultivated in Italy. Agr. Water Manage. 241:106336.

Caruso G, De Pascale S, Cozzolino E, Giordano M, El-Nakhel C, Cuciniello A, Rouphael Y, 2019a. Protein hydrolysate or plant extract-based biostimulants enhanced yield and quality performances of greenhouse perennial wall rocket grown in different seasons. Plants 8:208.

Caruso G, Giordano M, Cozzolino E, Cuciniello A, Cenvinzo V, Bonini P, Colla G, Rouphael Y, 2019b. Yield and nutritional quality of Vesuvian Piennolo tomato PDO as affected by farming system and biostimulant application. Agronomy 9:505.

Chapman NH, Bonnet J, Grivet L, Lynn J, Graham N, Smith R, Sun G, Walley PG, Poole M, Causse M, Graham JK, Baxter C, Seymour GB, 2012. High-resolution mapping of a fruit firmness-related quantitative trait locus in tomato reveals epistatic interactions associated with a complex combinatorial locus. Plant Physiol. 159:1644-57.

Colla G, Cardarelli M, Bonini P, Rouphael Y, 2017a. Foliar applications of protein hydrolysate, plant and seaweed extracts increase yield but differentially modulate fruit quality of greenhouse tomato. HortSci. 52:1214-20.

Colla G, Hoagland L, Ruzzi M, Cardarelli M, Bonini P, Canaguier R, Rouphael Y, 2017b. Biostimulant action of protein hydrolysates: Unraveling their effects on plant physiology and microbiome. Front. Plant Sci. 8:2202.

Colla G, Rouphael Y, Canaguier R, Svecova E, Cardarelli M, 2014. Biostimulant action of a plant-derived protein hydrolysate produced through enzymatic hydrolysis. Front. Plant Sci. 5:448.

Cozzolino E, Giordano M, Fiorentino N, El-Nakhel C, Pannico A, Di Mola I, Mori M, Kyriacou MC, Colla G, Rouphael Y, 2020. Appraisal of biodegradable mulching films and vegetalderived biostimulant application as eco-sustainable practices for enhancing lettuce crop performance and nutritive value. Agronomy 10:427.

de Jong M, Mariani C, Vriezen WH, 2009. The role of auxin and gibberellin in tomato fruit set. J. Expt. Bot. 60:1523-32.

Del Giudice R, Petruk G, Raiola A, Barone A, Monti DM, Rigano
MM, 2016. Carotenoids in fresh and processed tomato (Solanum lycopersicum) fruits protect cells from oxidative stress injury. J. Sci. Food Agric. 97:1616-23.

Di Mola I, Conti S, Cozzolino E, Melchionna G, Ottaiano L, Testa A, Mori M, 2021. Plant-based protein hydrolysate improves salinity tolerance in Hemp: agronomical and physiological aspects. Agronomy 11:342.

Di Mola I, Cozzolino E, Ottaiano L, Nocerino S, Rouphael Y, Colla G, Mori M, 2020a. Nitrogen use and uptake efficiency and crop performance of baby spinach (Spinacia oleracea L.) and lamb's lettuce (Valerianella locusta L.) grown under variable sub-optimal $\mathrm{N}$ regimes combined with plant-based biostimulant application. Agronomy. 10:278.

Di Mola I, Cozzolino E, Ottaiano L, Giordano M, Rouphael Y, ElNakhel C, Mori M, 2020b. Effect of seaweed (Ecklonia maxima) extract and legume-derived protein hydrolysate biostimulants on baby leaf lettuce grown on optimal doses of nitrogen under greenhouse conditions. Aust. J. Crop Sci.14:1456-64.

Di Mola I, Ottaiano L, Cozzolino E, Senatore M, Giordano M, ElNakhel C, Sacco A, Rouphael Y, Mori M, 2019. Plant-based biostimulants influence the agronomical, physiological, and qualitative responses of baby rocket leaves under diverse nitrogen conditions. Plants. 8:522.

Djidonou D, Zhao X, Simonne EH, Koch KE, Erickson JE, 2013. Yield, water and nitrogen-use efficiency in field-grown, grafted tomatoes. HortSci. 48:485-92.

du Jardin P, 2015. Plant biostimulants: definition, concept, main categories and regulation. Sci. Hortic. 196:3-14.

Du YD, Cao HX, Liu SQ, Gu, XB, Cao YX, 2017. Response of yield, quality, water and nitrogen use efficiency of tomato to different levels of water and nitrogen under drip irrigation in Northwestern China. J. Integr. Agr. 16:1153-61.

Ertani A, Pizzeghello D, Francioso O, Sambo P, Sanchez-Cortes S, Nardi S, 2014. Capsicum chinensis L. growth and nutraceutical properties are enhanced by biostimulants in a long-term period: Chemical and metabolomic approaches. Front. Plant Sci. 5:1-12.

Ertani A, Cavani L, Pizzeghello D, Brandellero E, Altissimo A, Ciavatta C, Nardi S, 2009. Biostimulant activity of two protein hydrolyzates in the growth and nitrogen metabolism of maize seedlings. J. Plant Nutr. Soil Sci.172:237-44.

Fernández V, Eichert T, 2009 Uptake of hydrophilic solutes through plant leaves: current state of knowledge and perspectives of foliar fertilization. Crit. Rev. Plant Sci 28:36-68.

Flores P, Hellin P, Fenoll J, 2009. Effect of manure and mineral fertilization on pepper nutritional quality. J. Sci. Food Agric. 89:1581-6.

Fogliano V, Verde V, Randazzo G, Ritieni A, 1999. Method for measuring antioxidant activity and its application to monitoring the antioxidant capacity of wines. J. Agric. Food Chem. 47:1035-40.

Hawkesford M, Kopriva S, De Kok L (Eds.), 2014. Nutrient use efficiency in plants - Concepts and approaches. Springer, Heidelberg, Germany.

Hawkesford M, Horst W, Kichey T, Lambers H, Schjoerring J, Møller IS, White P, 2012. Functions of macronutrients. In Marschner's mineral nutrition of higher plants. Acad. Press. 135-89.

Huang Y, Lu R, Chen K, 2018. Prediction of firmness parameters of tomatoes by portable visible and near-infrared spectroscopy. J. Food Engine. 222:185-98.

Kader AA, 2002. Postharvest technology of horticultural crops, p. 535. Division of Agriculture and Natural Resources, 
University of California, Publication n. 3311.

Kalt W, 2005. Effects of production and processing factors on major fruit and vegetable antioxidants. J. Food Sci. 70:R11-9.

Kampfenkel K, Van Montagu M, Inzé D, 1995. Extraction and determination of ascorbate and dehydroascorbate from plant tissue. Anal. Biochem. 225:165-7.

Khanam UKS, Oba S, Yanase E, Murakami Y, 2012. Phenolic acids, flavonoids and total antioxidant capacity of selected leafy vegetables. J. Funct. Foods 4:979-87.

Koukounararas A, Tsouvaltzis P, Siomos AS, 2013. Effect of root and foliar application of amino acids on the growth and yield of greenhouse tomato in different fertilization levels. J. Food Agric. Environ. 11:644-8.

Kyriacou MC, Rouphael Y, 2018. Towards a new definition of quality for fresh fruits and vegetables. Sci. Hortic. 234:463-9.

Lucini L, Rouphael Y, Cardarelli M, Canaguier R, Kumar P, Colla $\mathrm{G}$, 2015. The effect of a plant-derived biostimulant on metabolic profiling and crop performance of lettuce grown under saline conditions. Sci. Hortic. 182:124-33.

Maach M, Boudouasar K, Akodad M, Skalli A, Moumen A, \& Baghour M, 2020. Application of biostimulants improves yield and fruit quality in tomato. Int. J. Vege. Sci. 1-6.

Nangare DD, Singh Y, Kumar PS, Minhas PS, 2016. Growth, fruit yield and quality of tomato (Lycopersicon esculentum Mill.) as affected by deficit irrigation regulated on phenological basis. Agri. Water Manag. 171:73-9.

Nardi S, Pizzeghello D, Schiavon M, Ertani A, 2016. Plant biostimulants: Physiological responses induced by protein hydrolyzed-based products and humic substances in plant metabolism. Sci. Agric. 73:18-23.

Parađiković N, Vinković T, Vinković Vrček I, Žuntar I, Bojić M, Medić-Šarić M, 2011. Effect of natural biostimulants on yield and nutritional quality: an example of sweet yellow pepper plants (Capsicum annuum L.). J. Sci. Food Agri. 91:2146-52.

Re R, Pellegrini N, Proteggente A, Pannala A, Yang M, Rice-Evans C, 1999. Antioxidant activity applying an improved ABTS radical cation decolorization assay. Free. Radic. Biol. Med. 26:1231-7.

Rolland F, Moore B, Sheen J. 2002. Sugar sensing and signalling in plants. Plant Cell. 14:S185-205.

Ronga D, Pentangelo A, Parisi M, 2020. Optimizing N fertilization to improve yield, technological and nutritional quality of tomato grown in high fertility soil conditions. Plants 9:575.
Ronga D, Parisi M, Pentangelo A, Mori M, Di Mola I, 2019. Effects of nitrogen management on biomass production and dry matter distribution of processing tomato cropped in southern Italy. Agronomy 9:855.

Rouphael Y, Giordano M, Cardarelli M, Cozzolino E, Mori M, Kyriacou M, Bonini P, Colla G, 2018a. Plant and seaweedbased extracts increase yield but differentially modulate nutritional quality of greenhouse spinach through biostimulant action. Agronomy 8:126.

Rouphael Y, Kyriacou MC, Petropoulos SA, De Pascale S, Colla $\mathrm{G}, 2018 \mathrm{~b}$. Improving vegetable quality in controlled environments. Sci. Hortic. 234:275-89.

Rouphael Y, Colla G, Graziani G, Ritieni A, Cardarelli M, and De Pascale S, 2017a. Phenolic composition, antioxidant activity and mineral profile in two seed-propagated artichoke cultivars as affected by microbial inoculants and planting time. Food Chem. 234:10-9.

Rouphael Y, Colla G, Giordano M, El-Nakhel C, Kyriacou M C, \& De Pascale S, 2017b. Foliar applications of a legume-derived protein hydrolysate elicit dose-dependent increases of growth, leaf mineral composition, yield and fruit quality in two greenhouse tomato cultivars. Sci. Hortic. 226:353-60.

Schiavon M, Ertani A, Nardi S, 2008. Effects of an alfalfa protein hydrolysate on the gene expression and activity of enzymes of the tricarboxylic acid (TCA) cycle and nitrogen metabolism in Zea mays L. J. Agric. Food Chem. 56:11800-8.

Singleton VL, Orthofer R, Lamuela-Raventós RM, 1999. Analysis of total phenols and other oxidation substrates and antioxidants by means of Folin-Ciocalteu reagent. In: Methods in enzymology. Academic Press, Cambridge, MA, USA, 299:152-178.

Subbarao SB, Aftab Hussain IS, Ganesh PT, 2015. Biostimulant activity of protein hydrolysate: influence on plant growth and yield. J. Plant Sci. Res. 2:125.

Villarreal-Sánchez JA, Ilyina A, Mendez-Jiménez LP, RobledoTorres V, Rodríguez-Herrera R, Canales-López B, RodríguezMartínez J, 2003. Isolation of microbial groups from a seaweed extract and comparison of their effects on a growth of pepper culture (Capsicum annuum L.). Moscow Univ. Chem. Bull. 44:92-6.

Van Oosten MJ, Pepe O, De Pascale S, Silletti S, Maggio A, 2017. The role of biostimulants and bioe $\square$ ectors as alleviators of abiotic stress in crop plants. Chem. Biol. Technol. Agric. 4:5. 